\title{
The development of transnational company agreements in Europe
}

\section{Introduction}

This contribution describes a new phenomenon in the area of labour law and transnational labour relations: the emergence of transnational company agreements, often referred to as TCA's. ${ }^{1}$

Scholarly legal literature on the subject of transnational company agreements remains rather limited. The most relevant legal analyses are made by, or with cooperation of, the European Commission or the International Labour Organisation. A study of Ales and others (2006), ${ }^{2}$ which gives an overview of the current developments in transnational collective bargaining in Europe, includes a discussion on TCA's. Another interesting study is that of Papadakis and others (2008) on cross-border social dialogue and agreements, which includes a discussion on transnational company agreements within and beyond the European Union context. ${ }^{3}$

Furthermore, the European Union itself has produced a set of documents and texts on the issue of TCA's. From the European Commission, there is a Commission Staff Working Document (SEC(2008/)2155) on "The role of transnational company agreements in the context of an increasing international integration", 4 as well as the document on "Mapping of transnational texts negotiated at corporate level" (2008). ${ }^{5}$

The European Commission also organised two seminars on TCA's, one on 17 May 2006 and one on 27 November 2006. Documents and presentations used in these seminars can also be relied upon. Under the French presidency of the European Union (2008), some research has been undertaken as well. A document representing this research has been produced by Sobczak and Léonard $(2009)^{6}$ as well as by Carley. ${ }^{7}$

1 This contribution is based on research for a study, undertaken by the author and Aukje van Hoek, for the European Commission (VT/2008/102).

2 E. Ales, S. Engblom, T. Jaspers, S. Laulom, S. Sciarra, A. Sobczak, F. Valdés Dal-Ré, Transnational collective bargaining. Past, present and future. Final Report, 2006, 43 p.

3 K. Papadakis (ed.), Cross-border social dialogue and agreements, International Labour Office, Geneva, 2008, 288 p.

4 Commission Staff Working Document (SEC(2008) 2155), The role of transnational company agreements in the context of increasing international integration, Brussels, 2 July 2008, $\operatorname{COM}(2008) 419$ final, $11 \mathrm{p}$.

5 Mapping of transnational texts negotiated at corporate level, European Commission, Employment, Social Affairs and Equal Opportunities DG Social Dialogue, Social Rights, Working Conditions, Adaptation to Change, Brussels, 2 July 2008 EMPL F2 EP/bp 2008 (D) 14511, 37 p.

6 A. Sobczak and E. Léonard, Transnational social dialogue at the sector and the company level, Paper to be presented at the Conference of the Regulating for Decent Work network, Regulating for decent work: innovative regulation as a response to globalization, International Labour Office, Geneva, Switzerland, 8-10 July 2009, 17 p.

7 M. Carley, Report of the French EU Presidency conference "Transnational company agreements. Dialogue, rights, anticipating corporate restructuring, actors: A new perspective", Lyon, 13-14 November 2008, $39 \mathrm{p}$. 
Two relevant research projects of the European Foundation for Living and Working Conditions, also concern TCA's: the first is called "Bargaining at European level? Joint texts negotiated by European Works Councils" $(2001)^{8}$ and the second is called "European and international framework agreements: Practical experiences and strategic approaches" (2009). ${ }^{9}$ In addition, Welz has produced an extensive work on European social dialogue. ${ }^{10}$

A last project to be mentioned is a study commissioned by the European Commission on "International private law aspects of dispute settlement related to transnational company agreements" (VT/2008/102). The assigned study has been undertaken by Hendrickx and van Hoek. It is essentially concerned with the problem of enforcement of transnational company agreements. The study has not been published yet at the time of writing of the present contribution.

In 2004, the European Commission launched its Communication on "Partnership for change in an enlarged Europe - Enhancing the contribution of European social dialogue". ${ }^{11}$ In this Communication, the Commission referred to a 'new generation of texts' and the issue of the large diversity of documents and texts that resulted from social dialogue at Community level. It indicated the problems that come along as follows:

"The problem of the loose use of terminology by the social partners was first identified by the Commission in its Communication of June 2002, in which it called on the social partners to endeavour to clarify the terms used to describe their contributions and to reserve the term 'agreement' for texts implemented in accordance with the procedures laid down in Article 139(2) of the Treaty. Indeed the term 'agreement' has been employed in a very general way in the past. For example, it has been used for texts aimed at setting up social dialogue committees, as well as texts which essentially make recommendations, rather than being real 'agreements'."12

In the 2008 staff document, the Commission announced its intention to set up an expert group on transnational company agreements. This expert group was supplied by the Commission with information on some pertinent issues regarding transnational agreements, amongst which the private international law rules relevant for transnational texts.

In this contribution, the first purpose is to analyse in more detail the concept of transnational company agreements. This is done on the basis existing of studies and reports. The second purpose is to make an attempt to situate TCA's in the context of existing European labour law provisions, like the social policy Treaty framework as well as the European instruments on European Works Councils. The contribution will conclude with summary remarks and future prospects.

8 M. Carley, Bargaining at European level? Joint texts negotiated by European Works Councils, European Foundation for the Improvement of Living and Working Conditions, 2001, $94 \mathrm{p}$.

9 V. Telljohann, I. da Costa, T. Müller, U. Rehfeldt and R. Zimmer, European and international framework agreements: Practical experiences and strategic approaches, European Foundation for Living and Working Conditions, 2009, $95 \mathrm{p}$.

10 C. Welz, The European Social Dialogue under Articles 138 and 139 of the EC Treaty. Actors, Processes, outcomes, The Hague, Wolters Kluwer, 2008, 606 p.

11 European Commission, Partnership for change in an enlarged Europe - Enhancing the contribution of European social dialogue, Brussels, 12.8.2004, COM(2004)557final, 23 p.

12 European Commission, Partnership for change in an enlarged Europe - Enhancing the contribution of European social dialogue, Brussels, 12.8.2004, COM(2004)557final, 13-14. 


\section{Defining TCA's}

\section{Notion}

A transnational company agreement (TCA) is defined by the European Commission as "an agreement comprising reciprocal commitments the scope of which extends to the territory of several States and which has been concluded by one or more representatives of a company or a group of companies on the one hand, and one or more workers' organisations on the other hand, and which covers working and employment conditions and/or relations between employers and workers or their representatives". ${ }^{13}$

It must be pointed out that there is no real "single notion" or understanding of a transnational company agreement. There are many kinds of transnational texts negotiated at company level, with various names, formulas and looks capable to qualify as TCA's. Some of these texts use the word "agreement"; some use the word "declaration", or "protocol", or global agreement". It may be that not all TCA's may comprise strictly legal or binding obligations. Not all TCA's are applicable just to the European Union territory but may go further and have a global scope. Also the signatories may vary, such as European works councils, international unions, European unions, national unions, companies, multinational companies, etc.

TCA's cover a wide variety of topics: they are used not only to establish minimum labour standards as part of corporate social responsibility at the global level, but also as a means of promoting flexicurity at the company level. In addition they can contain commitments concerning information and consultation of workers' representatives or cover specific issues such as health and safety policies, equal opportunity policies and financial participation schemes.

\section{TCA's and IFA's}

TCA's show a lot of similarity with, and often qualify as, international framework agreements (IFA's). Torres has described IFA's as “instruments negotiated with global trade unions. The purpose of IFA's is to stimulate global social dialogue between the multinational and the representatives f workers - that is, both where the firm is headquartered and where it operates. IFA's also aim at promoting compliance with International Labour Organization core labour standards."14

In its "Mapping" document, ${ }^{15}$ the European Commission explained that, in 2008, out of the 147 transnational texts recorded, the following categories could be made:

13 Commission Staff Working Document (SEC(2008) 2155), The role of transnational company agreements in the context of increasing international integration, Brussels, 2 July 2008, $\operatorname{COM}(2008) 419$ final, footnote 2.

14 R. Torres, "Preface" in K. Papadakis (ed.), Cross-border social dialogue and agreements, Geneva, International Labour Office, 2008, v.

15 Mapping of transnational texts negotiated at corporate level, European Commission, Employment, Social Affairs and Equal Opportunities DG Social Dialogue, Social Rights, Working Conditions, Adaptation to Change, Brussels, 2 July 2008 EMPL F2 EP/bp 2008 (D) 14511, 3-4. 
- 76 texts were limited in scope or focus on the European area; they are called "European";

- 59 texts were focused on respect for fundamental rights primarily outside Europe; they are called "global";

- 12 texts were of global scope but also address specific European issues and/or very strongly involve the European Works Council; they are called "mixed".

The European Commission's "Mapping" document also explains that "a clear distinction of transnational texts, according to their scope and character, between "European" and "global" texts is not always possible as there is a continuum between both types and also both categories have had a quite comparable evolution over time."16

The similarities between IFA's and TCA's is also shown in the wide variety of wording and language used in the texts. In his research, Papadakis has indicated that "IFAs can be found under different names, for example "agreement on code of conduct" (IKEA in 1988); "joint declaration on human rights and working conditions" (BMW in 2005); "international framework agreement" (EADS in 2005); "global framework agreement on the development of good working conditions in operations worldwide" (Veidekke in 2005). Their common element is that they are negotiated instruments between MNEs and global union federations (GUFs), namely international federations of national unions by sector of activity." 17

The parallels between IFA's and TCA's would allow taking into account research findings on the (legal) enforcement of IFA's. But in these studies, the exact legal enforcement of the commitments that have been undertaken by the IFA signatories, remains generally an unresolved issue.

\section{TCA's and corporate strategies}

There is a close relationship between TCA's and corporate social responsibility ("CSR"). The European Commission defines CSR as "a concept whereby companies integrate social and environmental concerns in their business operations and in their interaction with their stakeholders on a voluntary basis." ${ }^{18}$ CSR is rather a strategy than a legal instrument. In a legal sense, CSR does not directly follow from law, nor does necessarily create (hard) law. However, this does not rule out that CSR strategies may result in the conclusion of an agreement, for example a transnational company agreement, or in the undertaking of (other) legal commitments.

This has been shown in a project supported by the European Foundation for the Improvement of Living and Working Conditions on "Codes of conduct and international

16 Mapping of transnational texts negotiated at corporate level, European Commission, Employment, Social Affairs and Equal Opportunities DG Social Dialogue, Social Rights, Working Conditions, Adaptation to Change, Brussels, 2 July 2008 EMPL F2 EP/bp 2008 (D) 14511, 4.

17 K. Papadakis, "Introduction" in K. Papadakis (ed.) Cross-border social dialogue and agreements, Geneva, International Labour Office, 2008, 2.

18 Green Paper Promoting a European framework for Corporate Social Responsibility Brussels, 18.7.2001, $\operatorname{COM}(2001) 366$ final, 6; Communication from the Commission concerning Corporate Social Responsibility: A business contribution to Sustainable Development Brussels, 2.7.2002, COM(2002)347final, 5. 
framework agreements: new developments in social regulation at company level", conducted from June 2006 to May 2007. This research had the objective of analysing the influence of IFA's, in comparison with codes of conduct, on MNE's behaviour in respect of labour conditions, social dialogue and corporate culture. ${ }^{19}$ One of the main conclusions has been that CSR strategies show a strong link with the strategies of concluding IFA's. ${ }^{20} 4$. A legal mapping of TCA's

What the comparison of TCA's with similar phenomena mainly learns is that the wide variety of documents and texts that qualify as TCA's, have to be placed (like IFA's, CSR strategies, and even corporate codes of conduct) in a continuum of private (legal) undertakings, varying from initiatives with low legal impact, over soft law mechanisms, to unilateral commitments and hard, legal, reciprocal rights and obligations. As a consequence, the question on whether TCA's are enforceable is strongly dependent on the legal nature of their commitments. A better understanding may be given by a short insight into the actual commitments that parties seem to be willing to undertake when concluding a TCA.

\section{a) TCA Parties}

In its "Mapping" document, the European Commission explains that "Transnational texts involve different sorts of parties and signatories: European Works Councils (EWCs), international and European Union organisations as well as national unions and national works councils. Over one third of the European and mixed transnational texts recorded and about two thirds of the global ones involve a combination of parties."21

\section{b) TCA Party intention}

In the context of the second Study Seminar on Transnational Agreements of 27 November 2006, some case studies were set up. From a limited number of TCA's, the involved actors and parties were asked about the kind of commitments they had undertaken. When asked "How do you see the text", the parties responded from "Not really or not only a political declaration", and "An agreement, but not really a collective agreement", to "Clearly a collective agreement, but a company one, and not only". When asked "What kind of legal commitments" were taken through the signing of TCA's, the parties re-

19 This research is reflected in the paper of: I. Schömann, "From CSR to International Framework Agreements: Towards an Internationalisation of Industrial Relations?", CSR PAPER 31.2007, 19 p. (downloadable at The Fondazione Eni Enrico Mattei Series Index: http://www.feem.it/ Feem/Pub/Publications/CSRPapers/default.htm.).

20 I. Schömann, 'From CSR to International Framework Agreements: Towards an Internationalisation of Industrial Relations?, CSR PAPER 31.2007, p16. (downloadable at The Fondazione Eni Enrico Mattei Series Index: http://www.feem.it/Feem/Pub/Publications/CSRPapers/default.htm.).

21 Mapping of transnational texts negotiated at corporate level, European Commission, Employment, Social Affairs and Equal Opportunities DG Social Dialogue, Social Rights, Working Conditions, Adaptation to Change, Brussels, 2 July 2008 EMPL F2 EP/bp 2008 (D) 14511, 8. 
sponded: "Commitments, but not a logic of rights, or "The agreements are legally binding" or we act as if they were". 22

The parties' intention with regard to the commitment that is undertaken when engaging into a TCA can also be deducted from the title these documents receive. In this respect, the European Commission's "Mapping" document ${ }^{23}$ indicates that that there is a wide diversity in the titles given to the transnational texts recorded. Out of the 88 European and mixed transnational texts:

- 36 texts include the word "agreement", "framework agreement", "global agreement", "European agreement", or "group agreement";

- 9 texts are called "principles", "guidelines" or "orientations";

- 7 texts are called "charters": “charter”, "social charter”, "European charter", "group social charter";

- 7 texts are called "declarations" or "joint declarations";

- 5 texts are called "joint opinion".

- 4 texts form an "annex" to the European Works Council or European Company involvement agreement or a part thereof;

- Other titles include "code of conduct", "procedure", "protocol”, "framework", "practices", "project", "action programme", or "convention".

From this record, no correspondence between the title of the text and the main issue addressed in it, was found. The same lack of correspondence can be seen between the title used and the kind of commitments that were expressed in the document.

It should, nevertheless, be noted that the wording used in various TCA's contain quite clear commitments. In a Working Document from the European Commission, some examples of TCA clauses can be found: ${ }^{24}$

- The company "will therefore supply information and the means for consultation to staff or their representatives in sufficient time";

- "Information will be provided in good time to enable representatives to appropriately prepare for consultation" ... "all parties will be bound by group collective and legislative requirements and the aim will be to reach adequate solutions";

- "Registration, filing and use of employee data is treated with strict confidentiality and in accordance with local legislation;

- the company will "refrain from any discrimination if national law does not expressly provide for the selection based on certain criteria";

- "Working hours are set according to the current laws and the industry norm; generally, a working week is not more than 48 hours and all employees receive a least one day off within a period of 7 days. Overtime is voluntary and as a rule restricted to no more than 12 hours per week. Each time this is compensated with an additional overtime payment, provided nothing different is agreed within flexible working arrangements";

22 European Commission, General Directorate Employment, Social Affairs and Equal Opportunities, Second study seminar "Transnational Agreements", 27 November 2006, Working document $\mathrm{n}^{\circ} 3$, Transnational agreements - Complementary Study, First findings, 6-10.

23 Mapping of transnational texts negotiated at corporate level, European Commission, Employment, Social Affairs and Equal Opportunities DG Social Dialogue, Social Rights, Working Conditions, Adaptation to Change, Brussels, 2 July 2008 EMPL F2 EP/bp 2008 (D) 14511, 7-8.

24 This is taken from a Working Document of E. Pichot (European Commission). 
- "Management and Employee Representatives will work together in good faith to find financially sustainable and socially responsible solutions for the necessary manpower adjustments. This includes that both parties will examine potential business opportunities in order to lessen the impact on employees";

- "Where a reduction in the staff of a subsidiary or a business unit within the Group becomes inevitable, the Group undertakes to inform the Group's European Works Council thereof at the same time as it sets up a body for concerted consultation between the HRM departments of the Group with a view to the redeployment in other business units of as many of the staff affected as possible; it undertakes to do this before instituting any dismissal procedure";

- the Companies "call upon the services of subcontractors with special skills and knowhow; The terms under which subcontractors are hired fully comply with social legislation and collective agreements concluded in the country in question".

\section{TCA's and European labour law}

It should be examined to what extent TCA's can be connected or show relevance with European labour law provisions. Some authors defend the idea that TCA's should be considered as 'national' agreements only. "They are nothing more and nothing less than agreements governed by national law or laws, having effect in different countries. They have no Community relevance and do not qualify as European transnational collective labour agreements." 25

This proposition can be questioned. Even in the absence of positive regulation of TCA's, they might be 'touched' or 'caught' by the provisions of European labour law. And if this is the case, it should be examined what legal consequences this may have. The value of this examination is reinforced by findings of the European Commission's "Mapping" document, ${ }^{26}$ in which it is said that "most of the texts called agreements do not have the legal character of a collective agreement under any national rules. However, at least nine can indeed be considered to be collective agreements at company or group level, since they were negotiated under French or Italian rules and concluded by national unions. They cover financial participation, anticipation of change, equal opportunities, health and safety, CSR and social dialogue. In addition, three "European agreements" have voluntarily been sent to the European Commission for "registration", in a move similar to national collective agreements which are to be sent to national administrations to that end."

If TCA's are not recognised as legal instruments under EU labour law, and if national labour laws do not qualify them as collective agreements, the possibility to look at these agreements as an autonomous (European) category "sui generis" should be left open.

25 S. Even, Transnational collective bargaining in Europe. A proposal for a European regulation on transnational collective bargaining, Den Haag, Boom Juridische Uitgaven, 2008, 231.

26 Mapping of transnational texts negotiated at corporate level, European Commission, Employment, Social Affairs and Equal Opportunities DG Social Dialogue, Social Rights, Working Conditions, Adaptation to Change, Brussels, 2 July 2008 EMPL F2 EP/bp 2008 (D) 14511, 8. 
At least, a connection of TCA's with existing European labour law sources may allow to develop better insight into the enforceability issue of such TCA's. The most relevant sources are Article 138-139 of the EC Treaty as well as the Directive (original and recast) on European Works Councils.

\section{Article 139 EC Treaty}

As TCA's are often related to the process of collective bargaining, the European Treaty framework on collective bargaining and social dialogue should be looked at. In particular, Article 139 EC Treaty seems relevant, as this article refers to the 'autonomous' or 'voluntary' initiative of social dialogue or collective bargaining at European level between 'management and labour'.

The issue of applicability of Article 139 EC Treaty on the issue of TCA's raises the question whether TCA's can fall under the provisions of this Treaty article. And if they do (not), what the meaning thereof is with regard to the problem of enforceability. There could be some impact on the question how such TCA's can be implemented.

For reasons of clarity, Article 139 EC Treaty is displayed:

Article 139 EC Treaty

"1. Should management and labour so desire, the dialogue between them at Community level may lead to contractual relations, including agreements.

2. Agreements concluded at Community level shall be implemented either in accordance with the procedures and practices specific to management and labour and the Member States or, in matters covered by Article 137, at the joint request of the signatory parties, by a Council decision on a proposal from the Commission.

The Council shall act by qualified majority, except where the agreement in question contains one or more provisions relating to one of the areas for which unanimity is required pursuant to Article 137(2). In that case, it shall act unanimously."

\section{a) Applicability of Article 139 EC Treaty}

Article 139, Paragraph 1, EC Treaty provides that, "should management and labour so desire, the dialogue between them at Community level may lead to contractual relations, including agreements." From the wording of this text, there is in principle no obstacle to also include company-level dialogue between 'management and labour'.

Article 139 EC Treaty is only applicable in so far as it concerns "dialogue between management and labour". It would seem obvious, taking into account the origins and the context of the provisions laid down in Article 138 and 139 EC Treaty, that the focus (has been and still) is, primarily, on dialogue between the cross-industry social partners (such as ETUC, BUSINESS EUROPE, CEEP and UEAPME). One form of evidence is that the Maastricht Agreement on Social Policy was strongly inspired by (and based on) an agreement of ETUC, UNICE and CEEP of 31 October $1991 .{ }^{27}$ These partners already had a social dialogue tradition, which was to be continued in light of the Treaty (or the Social Policy Agreement before that). This social partner focus was, in a further step,

27 See: Com (1993)600, 14. 
broadened to also include sector social partners. But things may look different as far as Article 139 EC Treaty is concerned. Seen the difference between social partner 'consultation' (Article 138 EC Treaty) and social partner 'negotiation' (Article 139 EC Treaty) - as stressed in the European Commission's 1993 Communication on social dialogue $^{28}$ - the range of 'voluntarily' negotiating social partners (Article $139 \mathrm{EC}$ Treaty) could be broader than the consulted social partners (Article 138 EC Treaty) in the institutional process.

Another issue is the specific type of social dialogue that is envisaged. From the wording of Article 139 EC Treaty, it appears that social dialogue activities and results will only be covered if they can be qualified as "contractual relations". In this regard, Article 139 EC Treaty distinguishes the concept of "contractual relations" from "agreements". This suggests a rather broad view of the notion "contractual relations". There is thus room for an interpretation including company-level contractual relations, leading to agreements.

Treu has been of the opinion that European company-level agreements do not fall under the EC Treaty's Social Chapter, basically on the ground that an implementation through Council Decision (Article 139 EC, Paragraph 2) is not suitable for such agreements. ${ }^{29}$ However, following Sciarra, "no theoretical framework appears suitable to include and describe European collective bargaining as it emerges from the Social Chapter". ${ }^{30}$ This leaves room for the construction of company-level agreements under the Treaty provisions.

\section{b) Consequences}

A 'reception' of European company-level agreements under the provisions of Article 139 of the EC Treaty, seems to have certain legal consequences. First, it gives the European Commission the task of promoting this form of social dialogue. Second, these agreements would need to be viewed in light of an autonomous European concept, although they may appear in multiple forms and are, sometimes, qualified as collective agreements at national level. Third, there may be an effect on the implementation of these agreements under article 139, second paragraph, of the EC Treaty, under which the rule would have to be followed that implementation is done according to the practices of the Member States.

\section{European Works Council Directive(s)}

Many TCA's have been concluded in the context of the activities of a European Works Council (EWC). Another matter is thus the issue of the relationship between EWC's

28 See: Com (1993)600, 15.

29 T. Treu,"European collective bargaining levels and the competences of the social partners" in P. Davies, A. Lyon-Caen, S. Sciarra and S. Simitis, European Community labour law: principles and perspectives, Oxford, Clarendon Press, 1996, 178.

30 Cf. S. Sciarra, "Collective agreements in the hierarchy of European Community sources", in P. Davies, A. Lyon-Caen, S. Sciarra and S. Simitis, European Community labour law: principles and perspectives, Oxford, Clarendon Press, 1996, 201. 
and the conclusion of TCA's. In fact, according to the European Commission's "Mapping" document, "European Works Councils are the main parties in European and mixed texts". ${ }^{31}$ In 2008, the Commission reported that "European Works Councils are signatories to 71 out of the 88 European and mixed transnational texts recorded". ${ }^{32}$ Existing research shows that some EWC agreements contain explicit reference to the possibility of concluding joint texts (TCA's). But other EWC agreements exclude this possibility. But the same research has also shown that there is no direct correlation between the EWC provisions on concluding TCA's versus actual practice. ${ }^{33}$

\section{a) Short overview of EWC legislation}

The European Works Council came into existence with the adoption of the European Directive 94/45/EC of 22 September 1994 on the establishment of an EWC or a procedure in Community-scale undertakings and Community-scale groups of undertakings for the purposes of informing and consulting employees. ${ }^{34}$ It is well known that this EWC 1994 Directive has had a great impact on European industrial relations.

Fifteen years after the adoption of Directive 94/45/EC, more than 800 European Works Councils are active, representing about 14.5 million employees with a view to providing them with information and consultation at transnational level.

However, some problems have been identified with regard to the practical application of Directive 94/45/EC, such as the lack of effectiveness or legal uncertainties, particularly with regard to the relationship between the national and transnational levels of consultation, and in cases of mergers and acquisitions. Also consistency and linkage of the various directives on the information and consultation of employees have been considered to be insufficient.

31 Mapping of transnational texts negotiated at corporate level, European Commission, Employment, Social Affairs and Equal Opportunities DG Social Dialogue, Social Rights, Working Conditions, Adaptation to Change, Brussels, 2 July 2008 EMPL F2 EP/bp 2008 (D) 14511, 8.

32 Mapping of transnational texts negotiated at corporate level, European Commission, Employment, Social Affairs and Equal Opportunities DG Social Dialogue, Social Rights, Working Conditions, Adaptation to Change, Brussels, 2 July 2008 EMPL F2 EP/bp 2008 (D) 14511, 9.

33 M. Carley, Bargaining at European level? Joint texts negotiated by European Works Councils, European Foundation for Living and Working Conditions, 2001, EF/01/52/EN, 17.

34 (94/95 EC) O.J.L 30 September 1994, 254/65. 
As a consequence, a revision of the Directive has been prepared. The European Commission has made a proposal for a Recast ${ }^{35}$ Directive of 2 July 2008 by. ${ }^{36}$ This finally has become Directive 2009/28/EC of 6 May 2009 amending Council Directive 94/45/ EC of 22 September 1994 on the establishment of a European Works Council or a procedure in Community-scale undertakings and Community-scale groups of undertakings for the purposes of informing and consulting employees, as extended to the United Kingdom by Council Directive 97/74/EC of 15 December 1997 and adapted by Council Directive 2006/109/EC of 20 November 2006 by reason of the accession of Bulgaria and Romania.

\section{b) The coverage of TCA's by the EWC Directive(s)}

It must be noted that TCA's have not been envisaged by the original 1994 EWC Directive. In the discussions leading to the 2009 Recast Directive, there was some attention for the issue of (company-level) social dialogue and its relation with the EWC legal framework. But TCA's in their strict sense seem to have remained outside the explicit scope of the Directives.

First, the EWC Directive (1994 and Recast) has been designed to realise information and consultation rights. Article 1, 1 of the 1994 EWC Directive provides that the purpose of this Directive is to improve the right to information and to consultation of employees in Community-scale undertakings and Community-scale groups of undertakings. However, especially the notions of consultation seems to have a rather broad meaning. Article 2, 1, (f) of the 1994 EWC Directive provides that 'consultation' means the exchange of views and establishment of dialogue between employees' representatives and central management or any more appropriate level of management.

Article 2, 1 of the 2009 Recast Directive goes further in defining the concept of information and consultation. The Recast Directive also includes 'establishment of dialogue' in its definition of consultation, which is done with a view to further clarify the

35 The term 'Recast' was used. The Working Party was also able to establish, in regard to the codification of the unchanged provisions of the previous act with the substantive amendments, that the proposal was indeed a straightforward codification without substantive changes to the acts to which it related (European Parliament, Draft Report of 23 September 2008 on the proposal for a directive of the European Parliament and of the Council on the establishment of a European Works Council or a procedure in Community-scale undertakings and Community-scale groups of undertakings for the purposes of informing and consulting employees (recast), (COM(2008)0419-C6-0258/2008 - 2008/0141(COD)), Committee on Employment and Social Affairs, Rapporteur: Philip Bushill-Matthews).

36 Proposal of 2 July 2008 for a European Parliament and Council Directive on the establishment of a European Works Council or a procedure in Community-scale undertakings and Community-scale groups of undertakings for the purposes of informing and consulting employees (Recast), COM(2008)419final. See Annex. 
concepts. ${ }^{37}$ It seems to have narrowed down the concept of 'consultation' however, by explicitly referring to its purposes. Preamble 23 of the Recast Directive explains that "the definition of "consultation" needs to take account of the goal of allowing for the expression of an opinion which will be useful to the decision-making process". According to Article 2, 1 (g) "consultation" means the establishment of dialogue and exchange of views between employees' representatives and central management or any more appropriate level of management, at such time, in such fashion and with such content as enables employees' representatives to express an opinion on the basis of the information provided about the proposed measures to which the consultation is related, without prejudice to the responsibilities of the management, and within a reasonable time, which may be taken into account within the Community-scale undertaking or Community-scale group of undertakings.

It would seem too far-reaching to include social dialogue and collective bargaining in the EWC's functions of providing information and consultation rights. Such limited view on information and consultation would also stem from the legal basis on which both EWC Directives have been based. ${ }^{38}$

On the other hand, 'contractual relations' or the conclusion of 'agreements' between workers representatives and management, are mentioned in the Directives.

\section{c) TCA's and EWC agreements}

The EWC Directive refers to the conclusion of agreements. One specific form of European-level agreements follows from Article 6, 1 of the 1994 EWC Directive (as well as the 2009 Recast Directive), which provides that "the central management and the special negotiating body must negotiate in a spirit of cooperation with a view to reaching an agreement on the detailed arrangements for implementing the information and consultation of employees provided for in Article 1 (1)". This system has been kept in the 2009 Recast Directive. In a broad view, it could be argued that the 'Article 6 agreement', concluded between central management and the special negotiating body ("SNB"), can be seen as a specific form of TCA, as it is concluded between (the central management of) a multinational employer (central management) on the one hand, and a group of worker representatives (or union delegates) of the company on the other hand. The European Commission's "Mapping" document, indicates that "transnational texts may play a complementary role in relation to the rules set down by the agreements established

37 Preamble 21 of the Recast Directive: "It is necessary to clarify the concepts of information and consultation of employees, in accordance with the definitions in the most recent Directives on this subject and those which apply within a national framework, with the objectives of reinforcing the effectiveness of dialogue at transnational level, permitting suitable linkage between the national and transnational levels of dialogue and ensuring the legal certainty required for the application of this Directive.".

38 Article 137, Paragraph 1, (e): "information and consultation of workers". 
under the provisions of the Community Directives aimed at establishing transnational information, consultation and participation mechanisms"39

'Article 6 agreements' that comply with Article 6, 2, (c) of the 1994 Directive (and the Recast), which provides that such agreement must include provisions on "the functions and the procedure for information and consultation of the European Works Council", come very close to TCA's which contain information and consultation rights or rights with regard to transnational business issues, such as business restructuring, that come within the scope of the EWC Directive.

This shows that the European EWC legislation is strongly interwoven with TCA's. But there remain differences. The main difference with the TCA as viewed here, is that an 'Article 6 agreement' is concluded between central management and the Special Negotiating Body (and/or its members) whereby a EWC is being set up, while most European TCA's are mainly concluded by EWC's themselves. Furthermore, the object and scope of a TCA is usually different then EWC agreements.

Another form of agreement follows from Article 13, 1 of the 1994 EWC Directive (cf. also Article 14 of the 2009 Recast Directive), which provides that "the obligations arising from this Directive shall not apply to Community-scale undertakings or Community-scale groups of undertakings in which (...) there is already an agreement, covering the entire workforce, providing for the transnational information and consultation of employees. One of the differences between 'Article 6 Agreements' and 'Article 13 Agreements' as regards their legal status, seems to be that the 1994 EWC Directive has allowed the latter to be concluded by a broader and more diverse range of signatories. They show, therefore, also characteristics similar to TCA's, without really playing the same role or covering the same issues as most TCA's.

\section{Conclusions}

A recent phenomenon concerns the issue of "transnational company agreements" (TCA's). The European Commission issued two major documents in this area. There is a Commission Staff Working Document (SEC(2008/)2155) on "The role of transnational company agreements in the context of an increasing international integration", ${ }^{40}$ as well as the document on "Mapping of transnational texts negotiated at corporate level" (2008). ${ }^{41}$ In these documents, TCA's are understood as "agreements comprising reciprocal commitments the scope of which extends to the territory of several States and which has been concluded by one or more representatives of a company or

39 Mapping of transnational texts negotiated at corporate level, European Commission, Employment, Social Affairs and Equal Opportunities DG Social Dialogue, Social Rights, Working Conditions, Adaptation to Change, Brussels, 2 July 2008 EMPL F2 EP/bp 2008 (D) 14511, 12 .

40 Commission Staff Working Document (SEC(2008) 2155), The role of transnational company agreements in the context of increasing international integration, Brussels, 2 July 2008, $\operatorname{COM}(2008) 419$ final, $11 \mathrm{p}$.

41 Mapping of transnational texts negotiated at corporate level, European Commission, Employment, Social Affairs and Equal Opportunities DG Social Dialogue, Social Rights, Working Conditions, Adaptation to Change, Brussels, 2 July 2008 EMPL F2 EP/bp 2008 (D) 14511, $37 \mathrm{p}$. 
a group of companies on the one hand, and one or more workers' organisations on the other hand, and which covers working and employment conditions and/or relations between employers and workers or their representatives".

The new generation of texts, such as TCA's, emphasise that many legal questions still remain in the area of European social dialogue and collective bargaining.

TCA's come under a wide variety of documents and texts. There is, as a consequence, no "single notion" of a transnational company agreement. TCA's cover a wide variety of topics and the commitments that are undertaken in TCA's may vary from loose unilateral commitments to hard reciprocal rights and obligations. There are strong parallels between IFA's and TCA's. This would allow taking into account research findings on the (legal) enforcement of IFA's. However, in these studies, the exact legal enforcement of the commitments that have been undertaken by the IFA signatories, seems to remain equally an unresolved issue.

This brings us to the question how TCA's are related to existing provisions of European labour law. From the above, it would seem that there may be a 'reception' of European TCA's under the provisions of Article 139 of the EC Treaty. There is also a 'light touch' with the EWC Directive. Taking into account the purposes and objectives of the EWC Directive (in both its original as well as in its recast form), it does not seem to give explicit competence to an EWC to conclude collective agreements or transnational company agreements. Although there are similarities between European TCA's, concluded within the framework of EWC's, on the one hand, and EWC agreements on the other hand, the EWC Directive does not seem to include TCA's in its scope of regulation. But it is also important to note that the EWC Directive does not exclude the conclusion of TCA's by EWC's either.

The Directive is confined with information and consultation. Especially the concept of "establishment of dialogue between employees' representatives and central management" shows similarities with company-level dialogue and bargaining activities. But the creation of collective bargaining has not been the objective of setting up the EWC directive.

It is clear that practice has gone beyond the strict legal environment. This was also concluded by the High Level Group on IR: "Although the EWCs usually have formal rights concerning information and consultation only, they represent networks of employees' representatives across borders, where local representatives are likely to meet on a regular basis. This may provide a basis for dialogue and co-ordination of bargaining." $" 42$

It could be argued that a mature system of collective bargaining, and thus a fully developed area of collective labour law, rests on three important pre-conditions: a legal framework, an institutional framework, and an industrial relations practice. The legal framework of collective labour law at the level of the European Union somehow exists, but with many shortcomings. It could also be said that, taking into account its limitedness, a certain practice of transnational collective labour relations has come into place. Both the institutional as well as the practical level of industrial relations have, in sum, developed "in the shadow of" a fairly limited legal framework.

42 Report of the High Level Group on Industrial Relations and Change in the European Union, Office for Official Publications of the European Communities, Luxembourg, 2002, 26. 
This situation needs to be looked at from the angle of international labour law, in particular ILO Convention $\mathrm{n}^{\circ} 98$ on collective bargaining. It can be argued that, seen the three abovementioned pre-conditions of collective bargaining (legal, institutional, practice), the fundamental right of collective bargaining requires that every competent level of jurisdiction must install a sufficient legal collective bargaining framework, whenever a significant practice is developing. Especially Article 4 of Convention $n^{\circ} 98$ is relevant where it provides that signatories have an obligation to take the necessary means "to encourage and promote the full development and utilisation of machinery for voluntary negotiation between employers or employers' organisations and workers' organisations, with a view to the regulation of terms and conditions of employment by means of collective agreements."

It is quite difficult for the European Union, viewed as a consistent system of governance, to make a global claim for fundamental collective labour rights, such as the right to collective bargaining, while maintaining a regulatory framework with rather low impact internally. It would seem that the European Commission is aware of this idea. In a Communication of 12 August 2004, entitled "Partnership for change", the European Commission stated that "in view of the growing number of new generation texts, the Commission considers there to be a need for a framework to help improve the consistency of the social dialogue outcomes and to improve transparency" ${ }^{43}$ As a consequence of this, the European Commission issued a study on transnational collective bargaining and announced to consult the social partners with a view to the creation of a Community framework for transnational collective bargaining. ${ }^{44}$ The Social Agenda 2005-2010 explicitly refers to this 'optional framework' of transnational collective bargaining. It is, however, clear that it concerns a sensitive issue and it will require a lot of work and patience to receive the full support of all stakeholders, including the employers organisations, involved.

$43 \operatorname{COM}(2004) 557$ final.

$44 \operatorname{COM}(2004) 557$ final, 12-13. 